\title{
Emission Pattern of Compression Ignition Engine Fueled with Blends of Tropical Almond Seed Oil-Based Biodiesel using Artificial Neural Network
}

\section{Samson Kolawole FASOGBON ${ }^{\mathrm{a}, \mathrm{b}, \mathrm{c}}$, Nathaniel B. JAGUNMOLU ${ }^{\mathrm{a}}$, Adesanya O. ADEYERA a , Akinola D. OGUNSOLA ${ }^{d}$, Olusegun O. LAOSEBIKAN ${ }^{\mathrm{a}}$}

\author{
${ }^{a}$ Department of Mechanical Engineering, University of Ibadan, Ibadan, Nigeria \\ ${ }^{\mathrm{b}}$ Centre for Petroleum, Energy Economics and Law, University of Ibadan, Nigeria \\ ${ }^{c}$ Department of Mechanical Engineering, Lagos State University, Epe Campus, Lagos, Nigeria \\ ${ }^{\mathrm{d} D e p a r t m e n t ~ o f ~ M e c h a n i c a l ~ E n g i n e e r i n g, ~ L a d o k e ~ A k i n t o l a ~ U n i v e r s i t y ~ o f ~ T e c h n o l o g y, ~ O g b o m o s h o, ~ N i g e r i a ~}$
}

Received: $9^{\text {th }}$ April 2021

Accepted: $21^{\text {st }}$ May 2021

Published:2nd September 2021

https://doi.org/10.47545/etrj.2021.6.2.084

\begin{abstract}
Engine pollutants have been a significant source of concern in most countries around the world because they are one of the major contributors to air pollution, which causes cancer, lung disorders, and other severe illnesses. The need to reduce emissions and its consequences has prompted studies into the emission profile of internal combustion engines running on particular fuels. To this end, this study employed the power of Artificial Neural Networks (ANNs) to investigate the impact of injection timing on the emission profile of Compression Ignition Engines fuelled with blends of Tropical Almond Seed Oil based-biodiesel; by conducting a series of experimental tests on the engine rig and using the results to train the ANNs; to predict the emission profile to full scale. Blend percentages, load percentages, and injection timings were used as input variables, and engine emission parameters were used as output variables, to train the network. The results showed that injection timing affect emission output of CI engines fuelled with Tropical Almond Oil based biodiesel; and for the emission pattern to be friendly, injection timing must rather be retarded and not advanced. The results also showed that for different engine emission parameters, there is a strong association between the ANN output results and the actual experimental values; with mean relative error values less than 10\%, which fall within the acceptable limits. For emission of CI engines fuelled with Tropical Almond Oil based biodiesel to be friendly in pattern, injection timing must be relatively retarded. The study also concluded that Artificial Neural Network (ANN) is a reliable tool for predicting Compression Ignition Engines emission profiles.
\end{abstract}

Keywords: Artificial neural networks, Biodiesel, Emissions, Injection timing, Tropical almond seed oil

\section{INTRODUCTION}

Due to dwindling fossil fuel supplies, increased crude oil costs, and growing environmental issues, a renewed emphasis on vegetable oils and animal fats as an alternative fuel supply, has emerged. The particular worries of the environmental issues have inspired scientists to investigate environmental friendly fuels for internal combustion engines [1, 2]. Diesel engines are generally utilized in power generation and transportation sector [3]. In spite the fact that diesel engines are usually preferable over gas engines, owing to higher thermal efficiency and lower Carbon (IV) Oxide $\left(\mathrm{CO}_{2}\right)$ emission, that notwithstanding, they produce higher Nitrogen Oxide (NOx) emissions and Particulate Matter (PM) [4, 5]. Unlike emissions from AGO/Diesel fuelled engines, vegetable oils fuelled engines decreases in particulate matter, HC, and Carbon Monoxide (CO) volumes [6]. Internal Combustion Engine manufacturers have developed alternatively fuelled engines and fuel systems that provide enough power yet stays within regulatory emission limits. Biodiesel holds promise as an alternative fuel for diesel engines, according to many experts, because its physicochemical characteristics is very similar to diesel [7]. Again, Biodiesel has a higher cetane number than petroleum diesel fuel, has no aromatics, and has a weight-based oxygen content of 10 - 11 percent [8]. As compared 
to diesel fuel, these properties of biodiesel eliminate carbon monoxide (CO), hydrocarbons (HC), and particulate matter (PM) pollution in the exhaust gas [9]. However, because biodiesel easily supports combustion due to its oxygen content, NOx emission increases [10]. Biodiesels are restricted as alternative fuel in diesel engines on the account of its high viscosity, flash point, pour point, cetane number and density; which brings about low fuel atomization and formation of unburnt fuels in combustion chambers [11-20].

Terminalia Catappa $L$. (Tropical Almond) has been proposed as a better source of biodiesel due its higher oil yield and heating value [21-22]. The higher oxygen content of biodiesel improves the burning efficiency and this remunerates the lower calorific value. Nonetheless, the kinematic viscosity, cetane number and relative density are about 44-45 percent, 7-8 percent, and 6-7 percent higher in biodiesel than ethanol; respectively. Biodiesel's higher viscosity can affect combustion characteristics due to the fact that viscosity has a minor impact on atomization efficiency. Because of the prevalent ignition characteristics, biodiesels have a higher cetane number, which helps with low engine working noise and great starting characteristics. The most notable difference between biodiesel and diesel fuel is that the former incorporates oxygen from the carboxyl group found in their structure, which is formed by a reaction with methanol [23]. The oxygen content of biodiesel is typically between 10 and 11 percent. Biodiesel does not have the same pour point as petrol. Biodiesel has a boiling point of about $350^{\circ} \mathrm{C}$, which is similar to the highest boiling hydrocarbons used in diesel fuel. Biodiesel has a small boiling range and functions similarly to single constituent fuels such as methanol. The low vapour pressure of biodiesel is not surprising given its small boiling range at high temperatures. Biodiesel's higher flash and fire points also provide greater safety while handling. Engine features, such as injection timing, have been shown to have a significant impact on the emissions and efficiency of biodiesel-fueled diesel engines [24]. Generic algorithm, non-linear regression and artificial neural network are the most well-known optimization procedures used in engine study [25]. The exhaust pollution and efficiency of mixed fuels have been predicted using an artificial neural network (ANN) [26]. It was discovered that ANN would accurately predict engine exhaust gas temperature and emissions, with correlation coefficients ranging from 0.983 to 0.996 [2729].

ANN was used by [30] to model the torque, strength, and emissions of a single-cylinder direct injection diesel engine running on diesel/biodiesel/alumina fuel blends. [31] evaluated and optimized the diesel engine parameters operated by pyrolysis oil/diesel/Tert-butyl hydroxyl quinone antioxidant blend. The combustion, efficiency, and emission characteristics of a diesel engine running on a diesel/biodiesel/diethyl ether blend were studied by [32], they found that $\mathrm{HC}, \mathrm{CO}$, and NOx decreased with blends increase. [33] tested injection timings in a dual fuel CI (Compression ignition) engine to see if they affect exhaust emissions. They experimented with ethanol blends with diesel at five different injection timings. They discovered that when injection timing was advanced, $\mathrm{NOx}$ and $\mathrm{CO}_{2}$ emissions increased while $\mathrm{HC}$ and $\mathrm{CO}$ emissions decreased. [34] experimented with a single cylinder diesel engine that operated on natural gas. When the injection timing was advanced by $5.5^{\circ}$, the engine performed erratically, but when it was reduced to $3.5^{\circ}$, the engine performed smoothly, particularly under low load conditions. Fuel intake increased significantly, while $\mathrm{CO}$ and $\mathrm{CO}_{2}$ emissions decreased. A neural network and generic algorithm were used by [35] to predict the NOx emissions and engine performance of a natural gas engine based on operating parameters, speed, and load. The engine performance increased, and NOx emissions got reduced. Artificial Neural Network (ANN) model was employed by [36] to predict exhaust gas temperature, efficiency, and emission of a spark ignition engine at different engine speeds. When comparing the expected ANN findings to the experimental data, the correlation coefficients ranged from 0.983 to 0.996 , with a low root mean square error. It was shown that the ANN method accurately forecasts IC engine emissions and efficiency. Review of Literature shows that Terminalia Catappa $L$. (Tropical Almond) seed oil based biodiesel has not been meaningfully analysed or modelled in CI engines. This study therefore employed the power of Artificial Neural Networks (ANNs) to investigate the impact of injection timing on the emission profile of Compression Ignition Engines fuelled with blends of Tropical Almond Seed Oil basedbiodiesel

\section{MATERIALS AND METHOD}

\subsection{Experiment Setup}

A single cylinder four stroke diesel engine was used for the performance evaluation. Figure 1 depicts a schematic diagram of the laboratory rig used to perform tests with various fuel blends (see Figure 2). An eddy current dynamometer is attached to a single cylinder four stroke water cooled compression ignition motor. 17.5:1 was the compression ratio. The engine's specifications are described in Table 1. Experiments were first carried out with straight diesel at different loads, then with tropical almond oil blends. Experiments with different injection timings were 
replicated. Table 2 shows the matrix of the tests carried out. Initially, the engine was powered on tidy diesel with a 21 ${ }^{\circ}$ bTDC injection timing. The engine was run in stages from no load to full load, with each run increasing the load by $25 \%$. The parameters NOx, CO, HC, and Smoke were registered once the steady state was achieved. Later, the engine was run on blends of methyl ester of Terminalia Catappa L. and diesel, which were blended in varying concentrations of $0 \%, 20 \%, 40 \%, 60 \%, 80 \%$, and $100 \%$ by volume, denoted by B0, B20, B40, B60, B80, and B100, respectively. The parameters of emission were also reported. As seen in Figures 3-4, the whole series of tests was replicated for injection timings of 24 and $27^{\circ} \mathrm{bTDC}$.

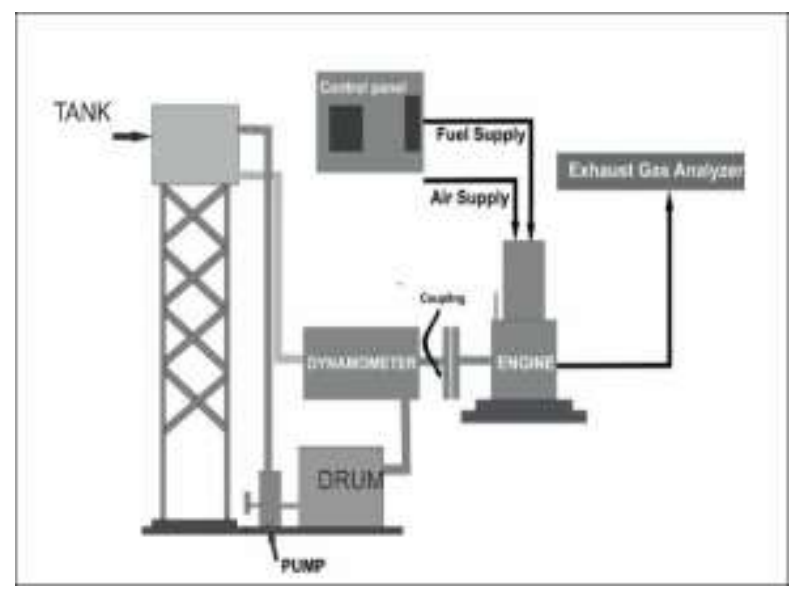

Figure 1. 2D-CAD drawing of the experimental rig

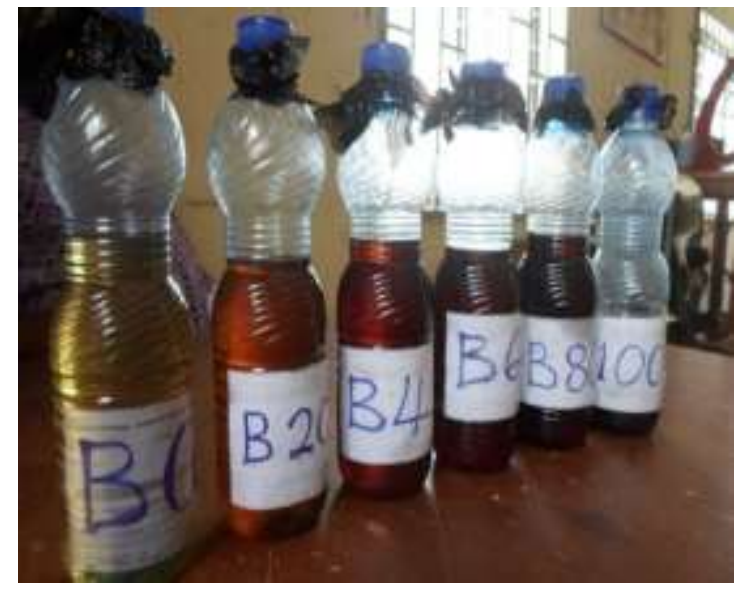

Figure 2. Various blends of TC-diesel fuels

\subsection{The Performance Indicators and ANN Execution}

Using steady-state experimental results, an ANN-based model for biodiesel engine parameters was created. The ANN model was used to calculate the amount of error in the experimental study's actual implementation. Artificial neural networks (ANNs) are powerful pattern recognition classifiers that are influenced by the structure and learning features of biological neuron cells. ANNs also found a wide range of applications, particularly with the advancement of computer technology [36]. Artificial neural networks are high-performance parallel information processing architectures. Artificial neural networks can solve complex problems thanks to these superior properties. Figure 5 depicts a basic model of the process element based on biological neurons. The performance of the process variable, $i$., is given in Eq. (1) in this model.

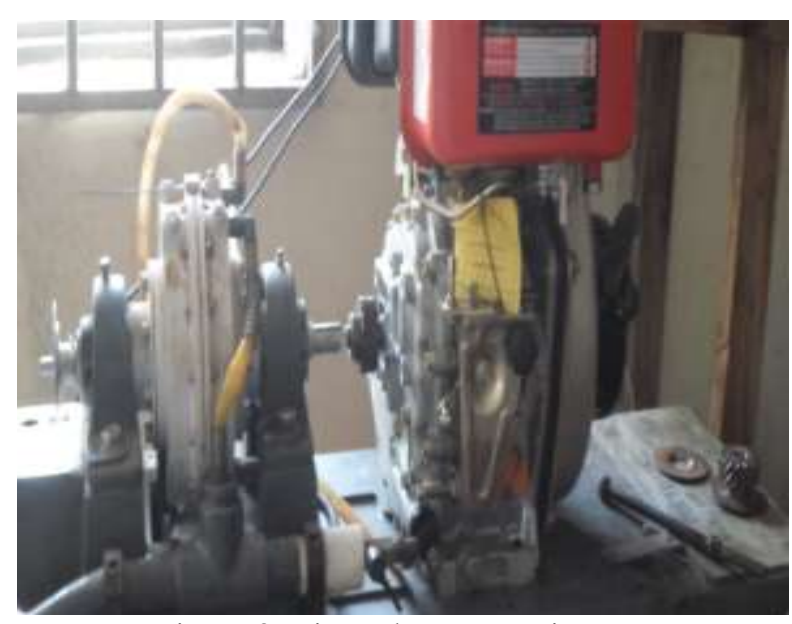

Figure 3. Rig under preparation

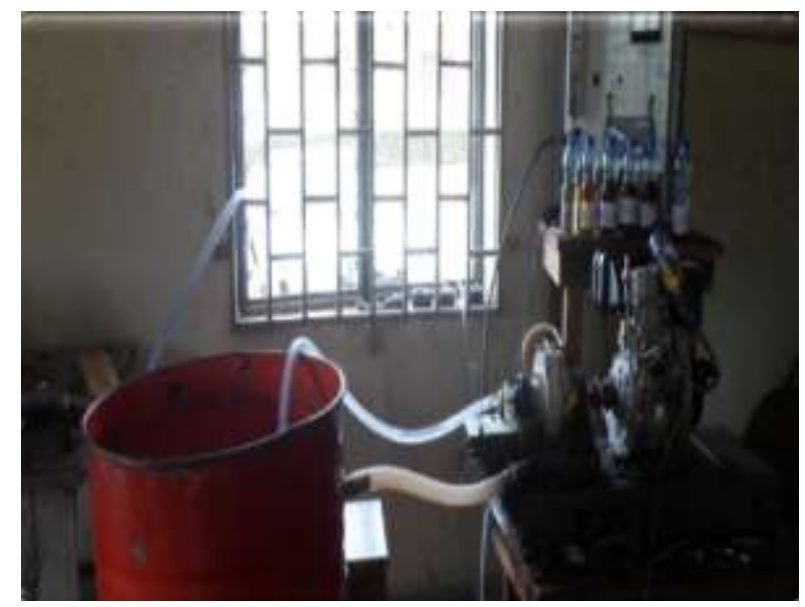

Figure 4. Rig now fully prepared and running

$$
y(t+1)=\propto\left(\sum_{j=1}^{m} w_{i j} x_{j}(t)-\theta_{i}\right)
$$


Table 1. Engine Technical Specifications

\begin{tabular}{|c|c|c|c|c|c|}
\hline Engine & & \multicolumn{4}{|c|}{$\begin{array}{l}\text { Constant speed diesel engine, four stroke, single } \\
\text { cylinder, water cooled }\end{array}$} \\
\hline Rated power & & \multicolumn{4}{|c|}{3.2 KW@ @ 1500 rpm } \\
\hline Stroke x Bore & & \multicolumn{4}{|c|}{$110 \times 87.5 \mathrm{~mm}$} \\
\hline Compression ratio & & \multicolumn{4}{|c|}{ 17.5:1 } \\
\hline Crank angle sensor & & \multicolumn{4}{|c|}{ Resolution $1^{\circ}$} \\
\hline Engine indicator & & \multicolumn{4}{|c|}{$\begin{array}{l}\text { To search data and interface with a Pentium III } \\
\text { processor }\end{array}$} \\
\hline Swept volume & & \multicolumn{4}{|c|}{$661 \mathrm{cc}$} \\
\hline \multicolumn{2}{|l|}{ Operating parameter } & \multicolumn{4}{|c|}{ Variations } \\
\hline Engine Load (\%) & 0 & 25 & 50 & 75 & 100 \\
\hline Tropical almond ester blend (\%) & 20 & 40 & 60 & 80 & 100 \\
\hline Injection timing ( $\left.{ }^{\circ} \mathrm{bTDC}\right)$ & 21 & 24 & 27 & & \\
\hline
\end{tabular}

where $\propto($.$) denotes the activation function and \theta_{i}=i$, denotes the processing element's threshold value. The computing elements' information processing is divided into two parts: input and output. By averaging the input information $x_{j}$ obtained from the outside over the $w_{i j}$ weights to which they are related, a processing unit produces a net value, $I$. Eq. (2) calculates the net worth of the processing variable.

$$
m e t=\left(\sum_{j=1}^{m} w_{i j} x_{j}-\theta_{i}\right)
$$

Each processing element's second step is to determine the output value by passing the net value through an activation function $\propto($.$) . The activation functions boost the performance of the process components over a broad range of values$ up to a certain point. As a result, each processing element's answer is smooth, and smaller values are guaranteed.

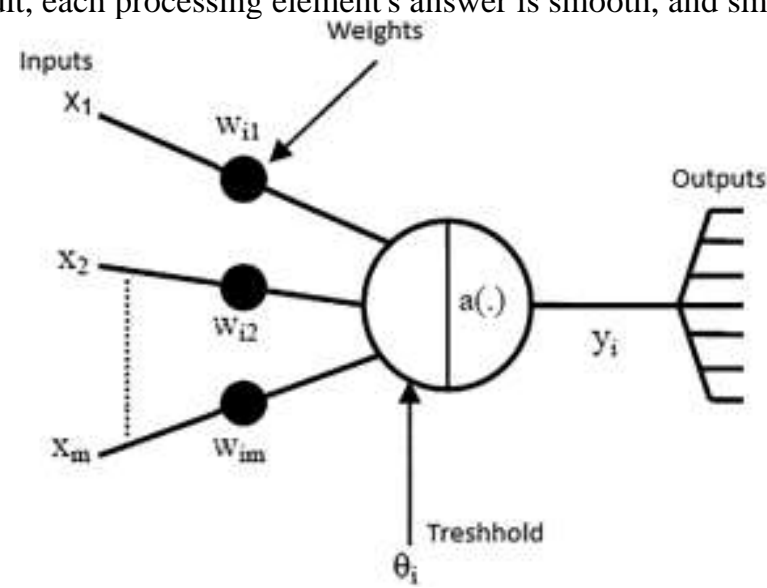

Figure 5. A neuron cell is mathematically modelled [36]

As a result, it helps to maintain reliability in artificial neural network training by avoiding error shift divergence. Unit move, sign-um, ramp, one- and two-way sigmoid functions are some of the most widely used activation functions [36]. The input layer, intermediate layer, and output layer make up this ANN model. The almond biodiesel blend ratio, load percentage, and injection timing were all inputs to the ANN. The ANN's performance parameters were emissions, which included nitrogen oxides (NOx), smoke (SN), hydrocarbon (HC) and carbon monoxide (CO). Figure 6 shows a flow map of the ANN and data processing processes to illustrate the procedures. 
Obtaining input and output parameters for all variables in the ANN model is required first. Seventy percent (70\%) of the experimental data was used in the model for the training set, while the remaining $30 \%$ was used for testing purposes. The input patterns are scaled in the range of 0.1 to 0.9 and presented to the network as a normalised array. The original values are normalized in order for the network to process them efficiently. The test results were compared to the predicted details during the test process. Once the test error reached the target amount, the network's training process was terminated [37]. The estimation performance of the models was measured using regression coefficients, MRE, and RMSE, which were generated with the goals and outputs of the ANN model. For calculation, the following equations were used [37]:

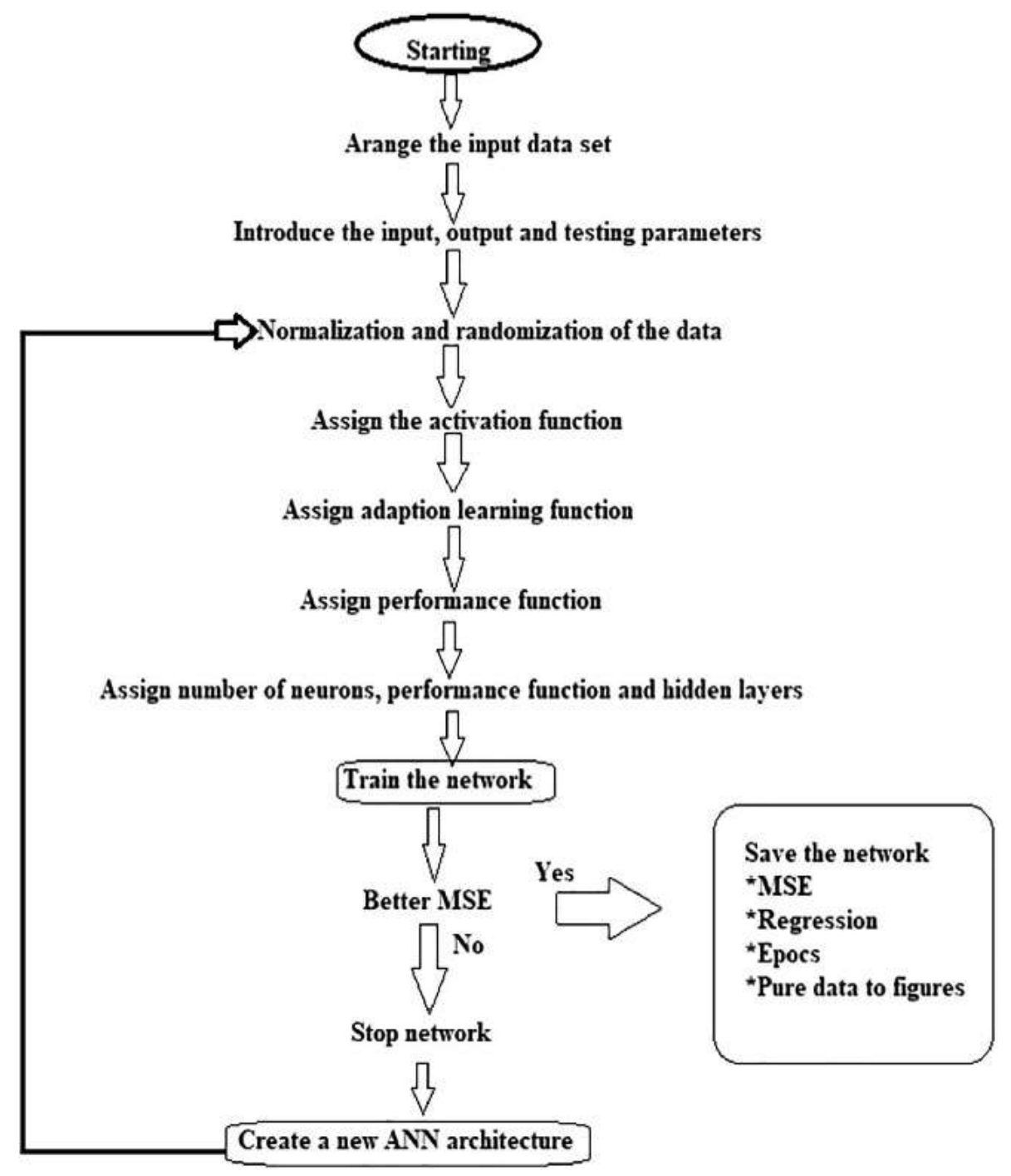

Figure 6. The ANN and computer analysis approaches flowchart [36]

$$
\begin{aligned}
& R^{2}=1-\left(\frac{\sum_{i=1}^{n}\left(t_{i}-o_{i}\right)^{2}}{\sum_{i=1}^{n}\left(o_{i}\right)^{2}}\right) \\
& \operatorname{MRE}(\%)=\frac{1}{n} \sum_{i=1}^{n} \mid 100 \frac{t_{i}-o_{i}}{t_{i}}
\end{aligned}
$$




$$
R M S E=\sqrt{\frac{1}{n} \sum_{i=1}^{n}\left(t_{i}-o_{i}\right)^{2}}
$$

where $\mathrm{n}$ is the number of information points in the group, o is the expected output data, and $\mathrm{t}$ is the actual output

\section{RESULTS AND DISCUSSION}

\subsection{NOx Emission}

The difference of NOx with injection timings is seen in Figure 7. On both diesel and biodiesel blends, NOx increased as the load increased. Since further fuel burns after TDC, cylinder pressure and temperature decreased when injection timings were delayed, lowering NOx emissions. NOx emissions for B20 at maximum load were reduced by 4.8 percent by delaying injection by $3^{\circ}$ from the usual value, which can be used as a combinational factor for reducing NOx emissions in a CI engine running on Tropical Almond Seed Oil based biodiesel. Figure 8 shows the expected NOx values and their experimental values at $21^{\circ} \mathrm{bTDC}$ injection timing. NOx was predicted by an ANN model with an MRE of 0.235 percent, an RMSE of $5.10 \mathrm{ppm}$, and a correlation coefficient of 0.999 . Figure 9 shows the MRE of 1.09 percent, RMSE of $3.07 \mathrm{ppm}$, and correlation coefficient of 1.09 percent for the ANN model forecast at $24^{\circ} \mathrm{bTDC}$ injection timing. Figure 10 depicts an overview of the expected and experimental NOx values at $27^{\circ} \mathrm{bTDC}$ injection timing. The ANN model prediction provided an MRE of 0.411 percent, RMSE of $13.91 \mathrm{ppm}$, and correlation coefficient of 0.999 .

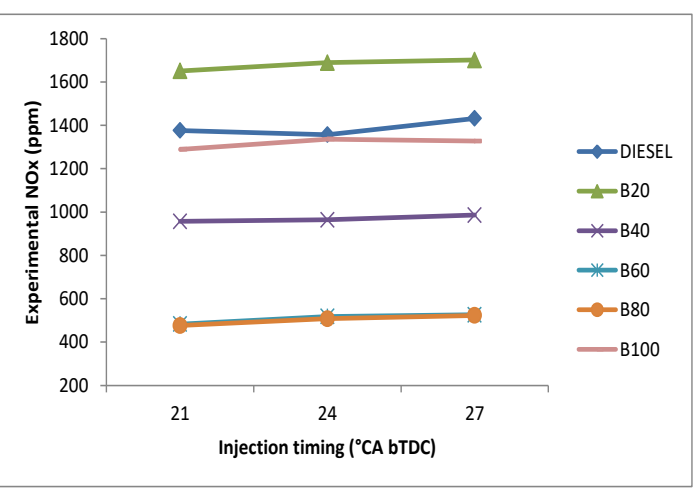

Figure 7 ANN predicted and experimental values of NOx versus injection timing

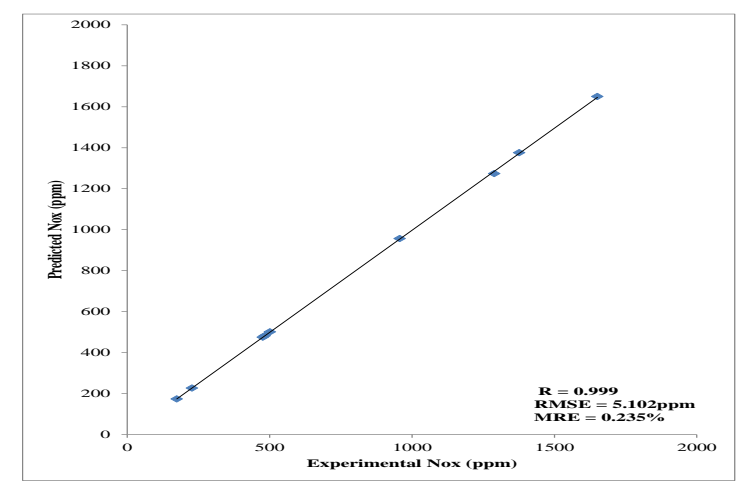

Figure 8 ANN predicted versus experimental values of NOx at $21^{\circ} \mathrm{bTDC}$

\subsection{Smoke emission}

Figure 11 depicts the effect of injection timing on smoke opacity. Smoke emissions rose from $21^{\circ} \mathrm{bTDC}$ to $24^{\circ} \mathrm{bTDC}$ injection timing and decreased as injection advance was increased from $24^{\circ} \mathrm{bTDC}$ injection timing. Figure 12 shows the MRE of 0.658 percent, RMSE of 0.87 percent, and correlation coefficient of 0.995 for the ANN model estimation of smoke at $21^{\circ} \mathrm{bTDC}$ injection timing. Figure 13 shows the MRE of 0.168 percent, RMSE of 1.01 percent, and correlation coefficient of 0.997 for the ANN model at $24{ }^{\circ} \mathrm{bTDC}$ estimation. Figure 14 shows an overview of the expected and experimental smoke values at $27^{\circ} \mathrm{bTDC}$. The ANN model prediction provided an MRE of 6.65 percent, RMSE of 0.99 percent, and correlation coefficient of 0.998.

\subsection{HC emission}

The difference of Hydro Carbon (HC) with injection timings is seen in Figure 15. Since the cylinder working temperature was higher and hence the reaction between fuel and oxygen was increased, delaying the injection timings decreased $\mathrm{HC}$ emissions. $\mathrm{HC}$ emissions rose by $10 \%$ to $20 \%$ when injection timing was improved by $3^{\circ}$, meaning that advanced injection timing would improve $\mathrm{HC}$ emissions for $\mathrm{CI}$ engines running on Tropical almond ester blends. Figure 16 displays the projected ANN model and experimental values for $\mathrm{HC}$ emissions at $21^{\circ} \mathrm{bTDC}$. With an MRE of 5.42 percent and an RMSE of $1.89 \mathrm{ppm}$, the correlation coefficient for $\mathrm{HC}$ is 0.967 . Figure 17 displays the contrast 


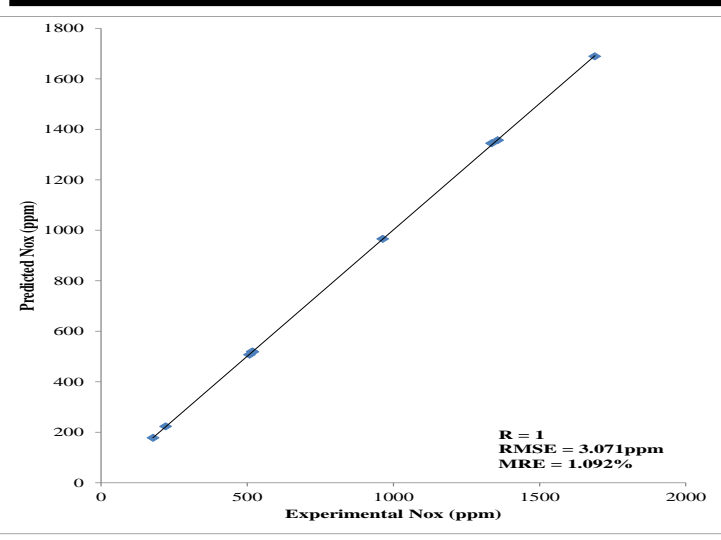

Figure 9 ANN predicted versus experimental values of NOx at $24^{\circ} \mathrm{bTDC}$

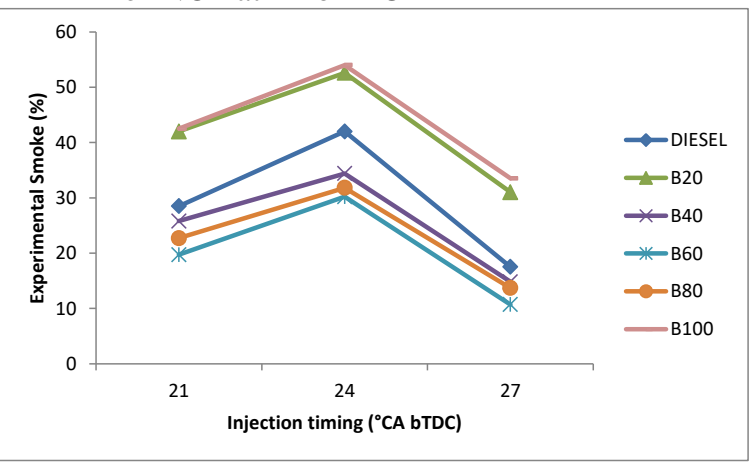

Figure 11: ANN predicted and experimental values of Smoke versus injection timing

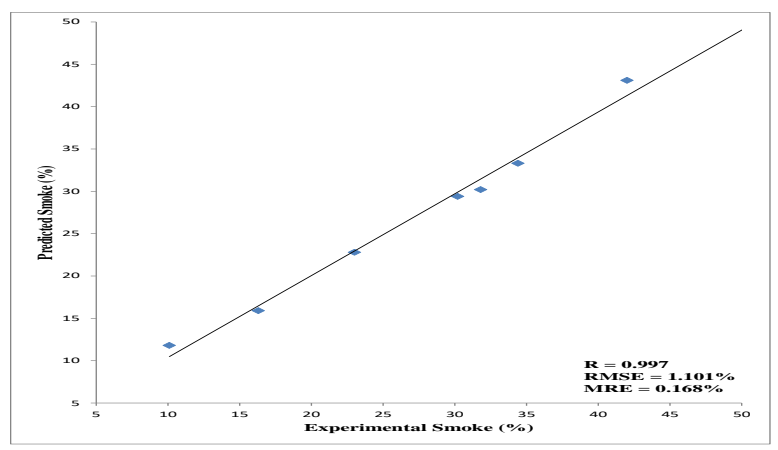

Figure 13: ANN predicted versus experimental values of smoke at $24^{\circ} \mathrm{bTDC}$

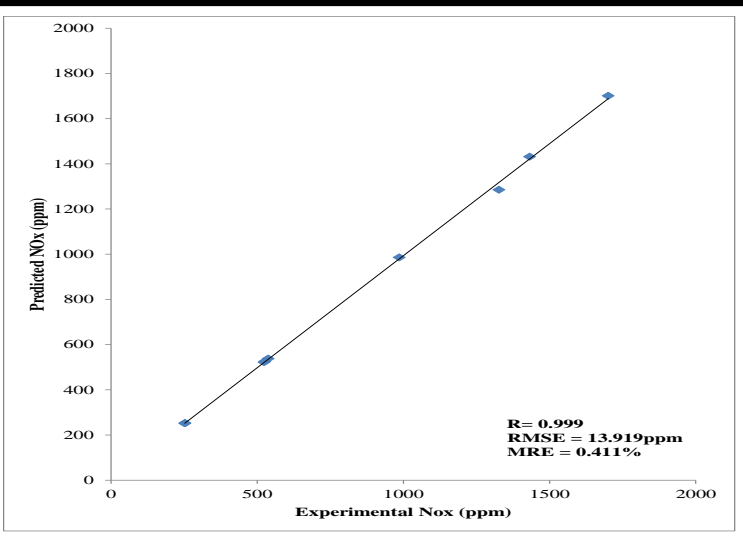

Figure 10 ANN predicted versus experimental values of NOx at $27^{\circ} \mathrm{bTDC}$

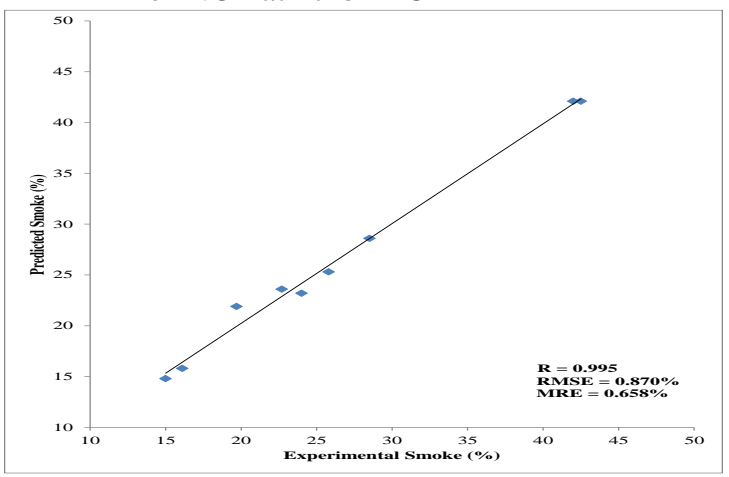

Figure $12 \mathrm{ANN}$ predicted versus experimental values of Smoke at $21^{\circ} \mathrm{bTDC}$

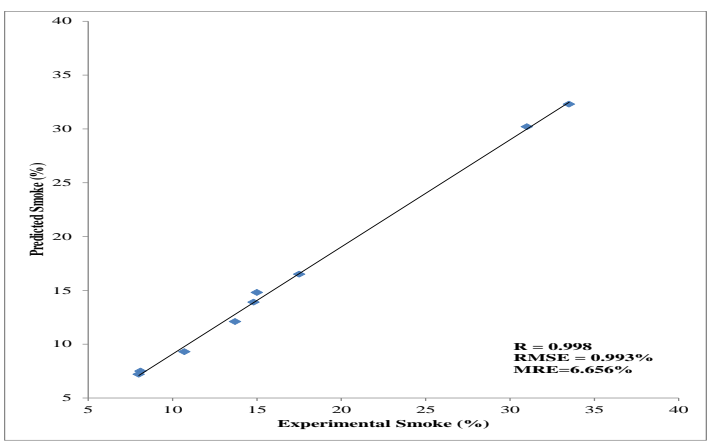

Figure 14: ANN predicted versus experimental values of smoke at $27^{\circ} \mathrm{bTDC}$

of ANN model expected and experimental values for $\mathrm{HC}$ emissions at $24^{\circ} \mathrm{bTDC}$. With an MRE of 1.38 percent and an RMSE of $0.738 \mathrm{ppm}$, the correlation coefficient for $\mathrm{HC}$ was 0.992 . Figure 18 displays the expected and experimental values for $\mathrm{HC}$ emissions at $27^{\circ} \mathrm{bTDC}$ using the ANN model. With an MRE of 1.36 percent and an RMSE of $0.589 \mathrm{ppm}$, the correlation coefficient for $\mathrm{HC}$ was 0.997 .

\subsection{CO emission}

The difference of Carbon II oxides (CO) with injection timings is seen in Figure 19. Since the cylinder working temperature was higher and hence the reaction between fuel and oxygen was increased, delaying the injection timings decreased CO emissions. CO emissions rose by $10 \%$ to $20 \%$ when injection timing was improved by $3^{\circ}$, meaning that advanced injection timing would improve $\mathrm{CO}$ emissions for $\mathrm{CI}$ engines running on Tropical almond ester blends. 
Figure 20 provides a comparison of $\mathrm{CO}$ emissions estimated by the ANN model and experimental values at $21^{\circ} \mathrm{bTDC}$. CO had a correlation coefficient of 0.993, with an MRE of 11.34 percent and an RMSE of $0.057 \%$ vol. Figure 21 displays the relation of $\mathrm{CO}$ emissions expected by the ANN model and experimental values at $24^{\circ} \mathrm{bTDC}$. CO had a correlation coefficient of 0.987 , with an MRE of 7.72 percent and an RMSE of $0.056 \%$ vol. Figure 22 depicts the ANN model's predicted and experimental $\mathrm{CO}$ emission values. $\mathrm{CO}$ had a correlation coefficient of 0.978 , with an MRE of $5.9 \%$ and an RMSE of $0.007 \%$ vol.

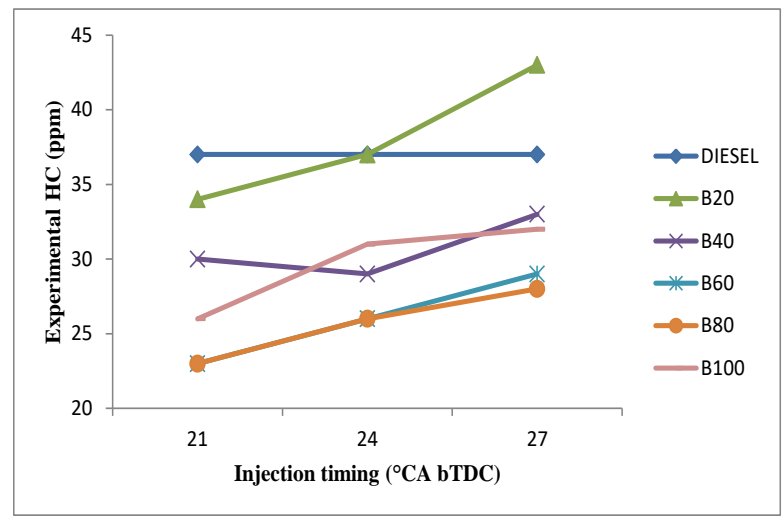

Figure 15: Variation of $\mathrm{HC}$ at different injection timings for different loads

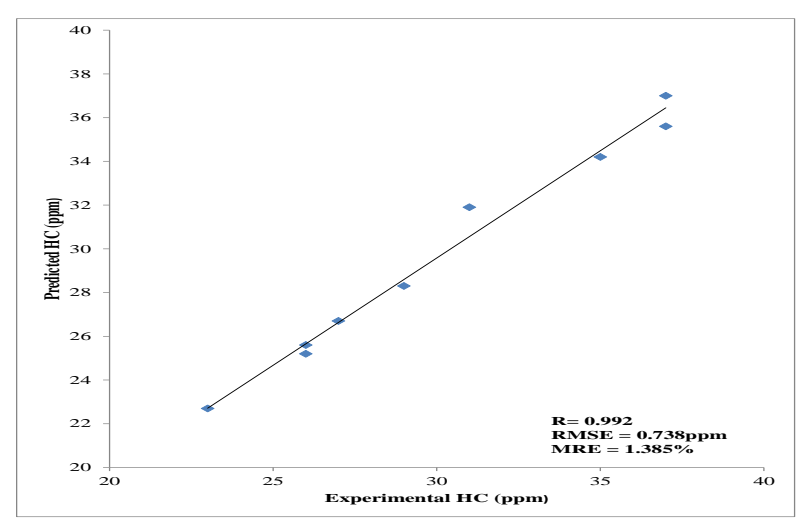

Figure 17: ANN predicted versus experimental values of $\mathrm{HC}$ at $24^{\circ} \mathrm{bTDC}$

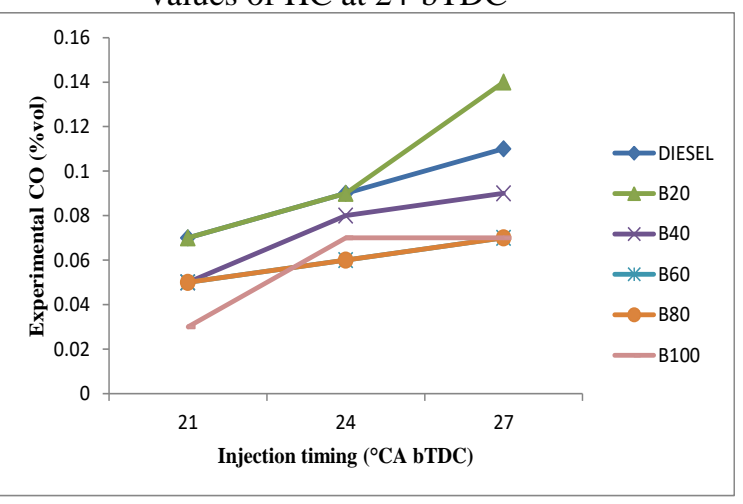

Figure 19: Variation of CO at different injection timings for different loads

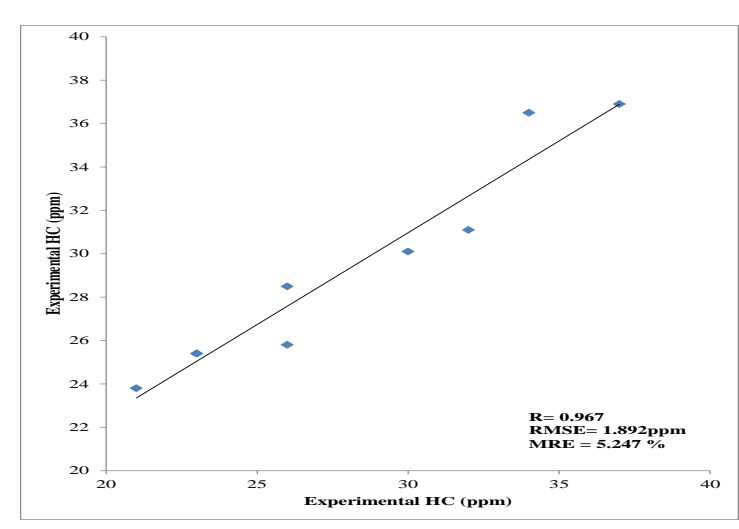

Figure 16: ANN predicted versus experimental values of $\mathrm{HC}$ at $21^{\circ} \mathrm{bTDC}$

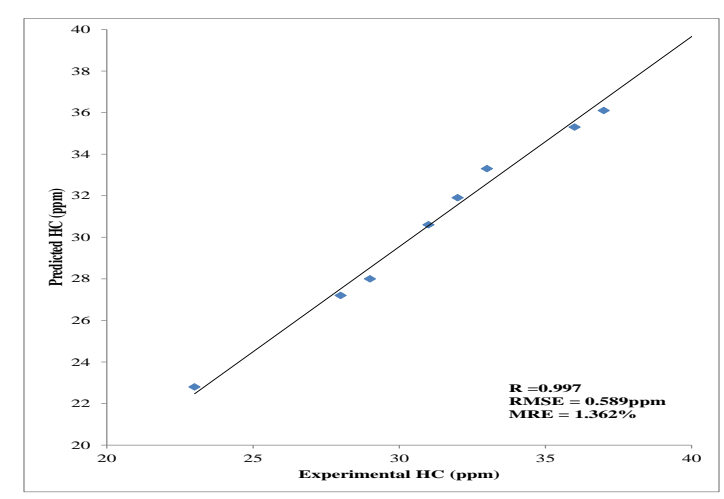

Figure 18: ANN predicted versus experimental values of $\mathrm{HC}$ at $27^{\circ} \mathrm{bTDC}$

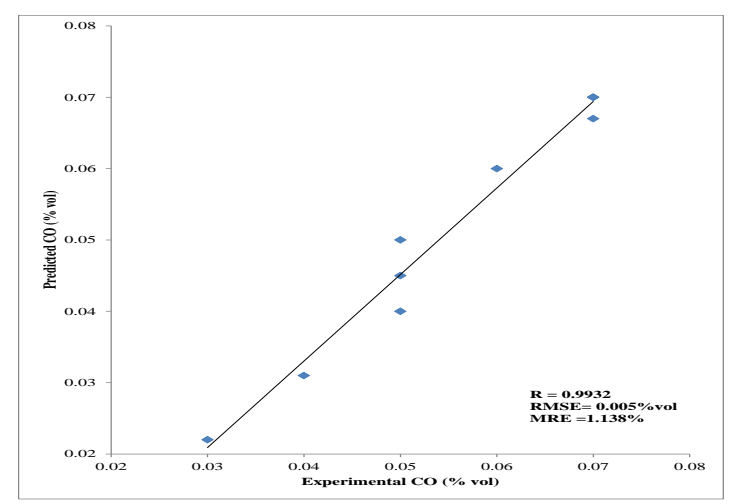

Figure 20: ANN predicted versus experimental values of $\mathrm{CO}$ at $21^{\circ} \mathrm{bTDC}$ 


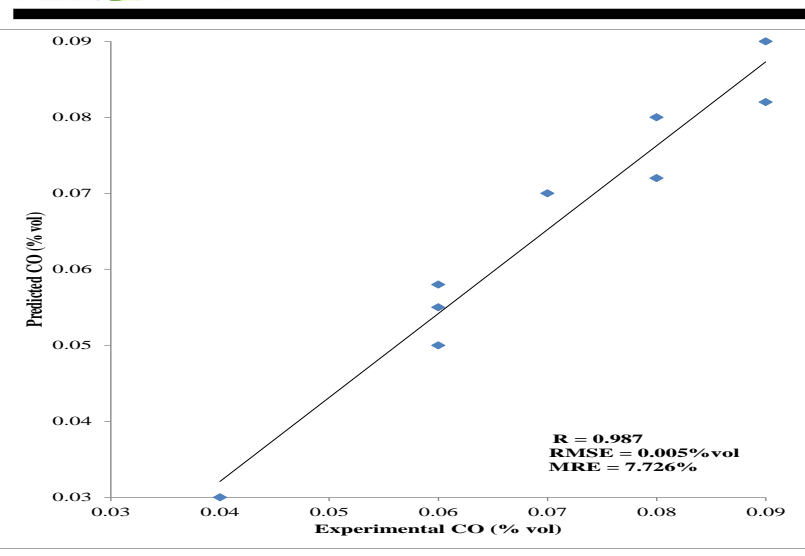

Figure 21: ANN predicted versus experimental values of $\mathrm{CO}$ at $24^{\circ} \mathrm{bTDC}$

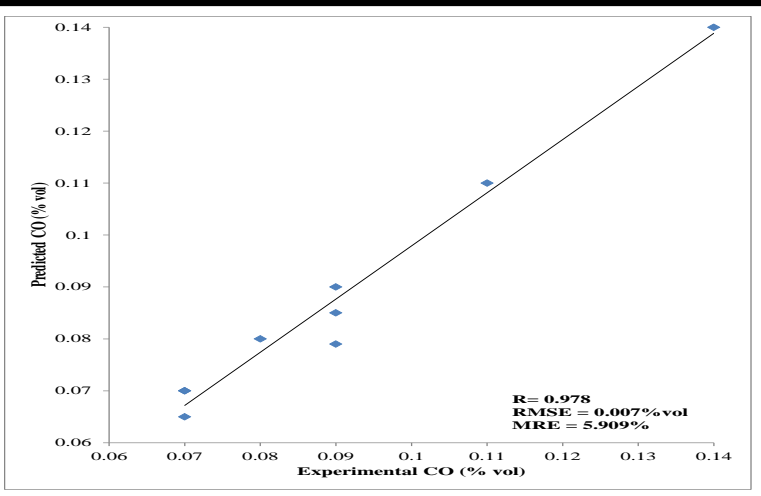

Figure 22: ANN predicted versus experimental values of $\mathrm{CO}$ at $27^{\circ} \mathrm{bTDC}$

\section{CONCLUSION}

This research was able to forecast the emission pattern of compression ignition engine running on blends of tropical almond seed oil based-biodiesel. The study here by draws the following conclusions:

(i) Advancing injection timing for $\mathrm{CI}$ engine fuelled with Tropical Almond Oil based biodiesel led to $\mathrm{CO}$ and $\mathrm{HC}$ exhaust gas emissions increase and NOx gas decrease, while retarding the injection timing gives reverse experience.

(ii) (ii) The MRE of the test results for the pollution parameters was also found to be below 10\%, which is satisfactory.

(iii) Artificial neural networks is a versatile tool for predicting the emission profile of CI engines powered with Tropical Almond Oil based biodiesel. As a result, the costs and time spent on experimental means can be significantly reduced.

\section{REFERENCES}

1. Karikalan, L., Jacob, S., Baskar, S., \& Venugopal, S. (2020). Analyzing the influence of varied fuel injection pressure on diesel engine fueled with Karanja biodiesel. Materials Today: Proceedings, 21(xxxx), 291-294. https://doi.org/10.1016/j.matpr.2019.05.439

2. Martins, F., Felgueiras, C., Smitkova, M., \& Caetano, N. (2019). Analysis of fossil fuel energy consumption and environmental impacts in european countries. Energies, 12(6), 1-11. https://doi.org/10.3390/en12060964

3. Goga, G., Chauhan, B. S., Mahla, S. K., \& Cho, H. M. (2019). Performance and emission characteristics of diesel engine fueled with rice bran biodiesel and n-butanol. Energy Reports, 5, 78-83. https://doi.org/10.1016/j.egyr.2018.12.002

4. Khalife, E., Tabatabaei, M., Demirbas, A., \& Aghbashlo, M. (2017). Impacts of additives on performance and emission characteristics of diesel engines during steady state operation. Progress in Energy and Combustion Science, 59, 32-78. https://doi.org/10.1016/j.pecs.2016.10.001

5. Calam, A. (2020). Effects of the fusel oil usage in HCCI engine on combustion, performance and emission. Fuel, 262(October), 116503. https://doi.org/10.1016/j.fuel.2019.116503

6. Hossain, A. K., \& Davies, P. A. (2010). Plant oils as fuels for compression ignition engines: A technical review and life-cycle analysis. Renewable Energy, 35(1), 1-13. https://doi.org/10.1016/j.renene.2009.05.009 
7. Kumar, C., Gajendra Babu, M. K., \& Das, L. M. (2006). Experimental investigations on a karanja oil methyl ester fueled DI diesel engine. SAE Technical Papers, 724. https://doi.org/10.4271/2006-01-0238

8. Raheman, H., \& Phadatare, A. G. (2004). Diesel engine emissions and performance from blends of karanja methyl ester and diesel. Biomass and Bioenergy, 27(4), 393-397. https://doi.org/10.1016/j.biombioe.2004.03.002

9. Ramadhas, A. S., Jayaraj, S., \& Muraleedharan, C. (2004). Use of vegetable oils as I.C. engine fuels - A review. Renewable Energy, 29(5), 727-742. https://doi.org/10.1016/j.renene.2003.09.008

10. Suryawanshi, J. G., \& Deshpande, N. V. (2005). Experimental investigations on a jatropha oil methyl ester fuelled diesel engine. Proceedings of the Spring Technical Conference of the ASME Internal Combustion Engine Division, 253-260. https://doi.org/10.1115/ICES2005-1040

11. Chandran, D. (2020). Compatibility of diesel engine materials with biodiesel fuel. Renewable Energy, 147, 89-99. https://doi.org/10.1016/j.renene.2019.08.040

12. Simsek, S. (2020). Effects of biodiesel obtained from Canola, sefflower oils and waste oils on the engine performance and exhaust emissions. Fuel, 265(December 2019), 117026. https://doi.org/10.1016/j.fuel.2020.117026

13. Uslu, S., \& Celik, M. B. (2020). Combustion and emission characteristics of isoamyl alcohol-gasoline blends in spark ignition engine. Fuel, 262(October 2019), 116496. https://doi.org/10.1016/j.fuel.2019.116496

14. Aydın, M., Uslu, S., \& Bahattin Çelik, M. (2020). Performance and emission prediction of a compression ignition engine fueled with biodiesel-diesel blends: A combined application of ANN and RSM based optimization. Fuel, 269(February). https://doi.org/10.1016/j.fuel.2020.117472

15. Elkelawy, M., Alm-Eldin Bastawissi, H., Esmaeil, K. K., Radwan, A. M., Panchal, H., Sadasivuni, K. K., Ponnamma, D., \& Walvekar, R. (2019). Experimental studies on the biodiesel production parameters optimization of sunflower and soybean oil mixture and DI engine combustion, performance, and emission analysis fueled with diesel/biodiesel blends. Fuel, 255(June), 115791. https://doi.org/10.1016/j.fuel.2019.115791

16. Simsek, S., \& Uslu, S. (2020). Determination of a diesel engine operating parameters powered with canola, safflower and waste vegetable oil based biodiesel combination using response surface methodology (RSM). Fuel, 270(February), 117496. https://doi.org/10.1016/j.fuel.2020.117496

17. Ogunkunle, O. and Ahmed, N. A. (2019). Performance evaluation of a diesel engine using blends of optimized yields of sand apple (Parinari polyandra) oil biodiesel. Renewable Energy, 134, 1320-1331. https://doi.org/10.1016/j.renene.2018.09.040

18. Gharehghani, A., \& Pourrahmani, H. (2019). Performance evaluation of diesel engines (PEDE) for a dieselbiodiesel fueled CI engine using nano-particles additive. Energy Conversion and Management, 198(August), 111921. https://doi.org/10.1016/j.enconman.2019.111921

19. Nirmala, N., Dawn, S. S., \& Harindra, C. (2020). Analysis of performance and emission characteristics of Waste cooking oil and Chlorella variabilis MK039712.1 biodiesel blends in a single cylinder, four strokes diesel engine. Renewable Energy, 147, 284-292. https://doi.org/10.1016/j.renene.2019.08.133

20. Akubude, V. C., Maduako,J. N., Egwuonwu, C. C., Olaniyan, A. M., Ajala, E. O., Ozumba, C. I., \& Nwosu, C. (2018). Effect of processing parameters on the expression efficiency of almond oil in a mechanical expression rig. Agricultural Engineering International: CIGR Journal, 20(1), 109-117.

21. Fasogbon, S. K., Fagbenle, R. O., \& Osunbunmi, I. S. (2016). Characterization of Terminalia Catappa Linn 
Oil , Linn Oil-based Methyl Ester and its Blends. African Journal of Sustainable Development, 6(2), 269281. https://www.ajol.info/index.php/ajsd/article/view/144043

22. Mehra, R. K., Duan, H., Luo, S., Rao, A., \& Ma, F. (2018). Experimental and artificial neural network (ANN) study of hydrogen enriched compressed natural gas (HCNG) engine under various ignition timings and excess air ratios. Applied Energy, 228(June), 736-754. https://doi.org/10.1016/j.apenergy.2018.06.085

23. Alonso, J. M., Alvarruiz, F., Desantes, J. M., Hernández, L., Hernández, V., \& Moltó, G. (2007). Combining neural networks and genetic algorithms to predict and reduce diesel engine emissions. IEEE Transactions on Evolutionary Computation, 11(1), 46-55. https://doi.org/10.1109/TEVC.2006.876364

24. Banapurmath, N. R., Tewari, P. G., \& Hosmath, R. S. (2008). Performance and emission characteristics of a DI compression ignition engine operated on Honge, Jatropha and sesame oil methyl esters. Renewable Energy, 33(9), 1982-1988. https://doi.org/10.1016/j.renene.2007.11.012

25. Xue, J., Grift, T. E., \& Hansen, A. C. (2011). Effect of biodiesel on engine performances and emissions. Renewable and Sustainable Energy Reviews, 15(2), 1098-1116. https://doi.org/10.1016/j.rser.2010.11.016

26. Canakci, M., Erdil, A., \& Arcaklioğlu, E. (2006). Performance and exhaust emissions of a biodiesel engine. Applied Energy, 83(6), 594-605. https://doi.org/10.1016/j.apenergy.2005.05.003

27. Sayin, C., Ertunc, H. M., Hosoz, M., Kilicaslan, I., \& Canakci, M. (2007). Performance and exhaust emissions of a gasoline engine using artificial neural network. Applied Thermal Engineering, 27(1), 46-54. https://doi.org/10.1016/j.applthermaleng.2006.05.016

28. Ganapathy, T., Murugesan, K., \& Gakkhar, R. P. (2009). Performance optimization of Jatropha biodiesel engine model using Taguchi approach. Applied Energy, 86(11), 2476-2486. https://doi.org/10.1016/j.apenergy.2009.02.008

29. Hosseini, S. H., Taghizadeh-Alisaraei, A., Ghobadian, B., \& Abbaszadeh-Mayvan, A. (2020). Artificial neural network modeling of performance, emission, and vibration of a CI engine using alumina nano-catalyst added to diesel-biodiesel blends. Renewable Energy, 149, 951-961. https://doi.org/10.1016/j.renene.2019.10.080

30. Baranitharan, P., Ramesh, K., \& Sakthivel, R. (2019). Measurement of performance and emission distinctiveness of Aegle marmelos seed cake pyrolysis oil/diesel/TBHQ opus powered in a DI diesel engine using ANN and RSM. Measurement: Journal of the International Measurement Confederation, 144, 366380. https://doi.org/10.1016/j.measurement.2019.05.037

31. Krishnamoorthi, M., Malayalamurthi, R., \& Sakthivel, R. (2019). Optimization of compression ignition engine fueled with diesel - chaulmoogra oil - diethyl ether blend with engine parameters and exhaust gas recirculation. Renewable Energy, 134, 579-602. https://doi.org/10.1016/j.renene.2018.11.062

32. Sayin, C., Uslu, K., \& Canakci, M. (2008). Influence of injection timing on the exhaust emissions of a dualfuel CI engine. Renewable Energy, 33(6), 1314-1323. https://doi.org/10.1016/j.renene.2007.07.007

33. Nwafor, O. M. I. (2007). Effect of advanced injection timing on emission characteristics of diesel engine running on natural gas. Renewable Energy, 32(14), 2361-2368. https://doi.org/10.1016/j.renene.2006.12.006

34. Kesgin, U. (2004). Genetic algorithm and artificial neural network for engine optimisation of efficiency and NOx emission. Fuel, 83(7-8), 885-895. https://doi.org/10.1016/j.fuel.2003.10.025

35. Bahattin, I. (2020). ANN modeling for justi fi cation of thermodynamic analysis of experimental applications on combustion parameters of a diesel engine using diesel and sa ffl ower biodiesel fuels. 279(May). https://doi.org/10.1016/j.fuel.2020.118391 
36. Uslu, S., \& Celik, M. B. (2018). Prediction of engine emissions and performance with artificial neural networks in a single cylinder diesel engine using diethyl ether. Engineering Science and Technology, an International Journal, 21(6), 1194-1201. https://doi.org/10.1016/j.jestch.2018.08.017 